\title{
Analisis Budaya Organizational Culture Assesment Instrument (OCAI) pada Pejabat Struktural di RS Islam Surabaya
}

\author{
Akas Yekti Pulih Asihํㅡ, Budhi Setianto², Agus Aan Adriansyah ${ }^{3}$ \\ 1,2,3Program Studi Kesehatan Masyarakat, Fakultas Kesehatan, Universitas Nahdlatul Ulama Surabaya \\ akasyekti@unusa.ac.id ${ }^{1}$, budhisetanto@yahoo.com², aan.naufal87@unusa.ac.id ${ }^{3}$
}

Diajukan 8 November 2021 Diperbaiki 28 November 2021 Diterima 30 November 2021 ABSTRAK

Latar Belakang: Budaya organisasi merupakan salah satu tata nilai dalam membangun organisasi yang efektif. Budaya organisasi menjadi kewajiban yang perlu tumbuh dalam membentuk ciri khas perilaku organisasi serta perilaku individu di dalamnya yang membentuk citra organisasi di masyarakat selaku pemakai produk yang dihasilkan oleh organisasi tersebut.

Tujuan: Memetakan budaya organisasi pada pejabat struktural di Rumah Sakit Islam Surabaya.

Metode: Penelitian ini bersifat deskriptif dengan melibatkan seluruh pejabat struktural di RS Islam Surabaya sebagai responden yang berjumlah 63 orang. Analisis data dilakukan dengan pengukuran terhadap rerata antara pelaksanaan budaya organisasi yang telah terlaksana dengan kondisi ideal yang diharapkan oleh pejabat struktural. Penilaian dilakukan dengan menggunakan metode Organization Culture Asessement Instrument (OCAI).

Hasil: Budaya Organizational Culture Assesment Instrument (OCAI) pejabat struktural, telah sesuai antara harapan dan kenyataan. Perbedaan antara harapan dan kenyataan budaya Clan dan Hierarchy adalah 1,95 dan 1,26. Budaya Pejabat Struktural RS Islam Surabaya saat ini didominasi dengan budaya Hierarchy dan budaya Clan.

Kesimpulan: Kunci sukses keberhasilan budaya organisasi ditunjukkan dengan tidak adanya gap antara harapan dan kenyataan. Budaya Hierarchy menunjukkan bahwa organisasi sudah memiliki tatanan dan mengharuskan seluruh pejabat melakukan kebijakan tersebut, sedangkan budaya Clan menandakan bahwa RS Islam Surabaya merupakan tempat bekerja yang hangat, memiliki susana kekeluargaan, dan setiap individu saling mengisi satu sama lain.

Kata Kunci: Budaya Organisasi; OCAI; Pejabat Struktural

\section{ABSTRACT}

Background: Organizational culture is one of the values in building an effective organization. Organizational culture is an obligation that needs to grow in shaping the characteristics of organizational behavior and individual behavior in it which forms the image of the organization in society as users of the products produced by the organization.

Objective: Mapping organizational culture on structural officials at the Surabaya Islamic Hospital.

Methods: This research is descriptive in nature by involving all structural officials at the Surabaya Islamic Hospital as respondents, totaling 63 people. Data analysis is carried out by measuring the average between the implementation of organizational culture that has been implemented and the ideal conditions expected by structural officials. The assessment is carried out using the Organization Culture Assessment Instrument (OCAI) method.

Results: The Organizational Culture Assessment Instrument (OCAI) has been matched between the expectations and the reality. The difference between the expectations and realitites of the Hierarchy and Clan Cultures are 1.95 and 1.26. The Culture of the structural of Surabaya Islamic Hospital is currently dominated by Hierarchy and Clan Culture.

Conclusion: The key to success of organizational culture was shown by no gap between expectation and reality. Hierarchy culture shows that the organization already has an order and requires all officials to carry out these policies, while Clan culture indicates that Surabaya Islamic Hospital was a warm place to work, has a family atmosphere, and every individual complements each other.

Keywords: Organizational Culture; OCAI; Structural Officer 
PENDAHULUAN

Budaya organisasi merupakan suatu aturan yang wajib dilaksanakan sebagai sebuah persepsi karyawan dalam melaksanakan organisasi untuk menjadi satu kesatuan sistem yang memiliki kesamaan pengertian dalam suatu sudut pandang yang sama (Hamid \& Mukzam, 2016). Budaya organisasi termasuk sesuatu yang diperlukan untuk pertumbuhan dan membentuk perilaku atau karakter dalam organisasi (Wijaya, 2016).

Perilaku individu merupakan satu kesatuan yang didalamnya membentuk citra organisasi pada masyarakat. Kepedulian terhadap organisasi yangditunjukkan harus berawal pada saat perusahaan didirikan dengan cara menetapkan suatu visi dan misi perusahaan (Umartias, 2014).

Visi dan misi merupakan roda penggerak dari sebuah organisasi sehingga menjadi suatu hal penting bagi sebuah perusahaan untuk memiliki visi dan misi (Vidyastuti, 2019). Secara sederhana, dalam pelaksanaannya, suatu budaya organisasi merupakan rangkaian nilai organisasi yang muncul untuk membentuk perilaku secara bersamaan beserta anggota didalamnya (Nadirasetya, 2016).

Proses penentuan posisi pasar dan teknologi yang baik tidak akan maksimal jika tidak diiringi dengan adanya budaya organisasi yang khas dalam pelaksanaannya (Setyaningsih, 2013). Budaya organisasi merupakan suatu ciri khas sebuah organisasi. Perusahaan yang memiliki budaya organisasi akan mampu menarik peluang usaha yang memberikan nilai lebih baik dan lebih kuat dibandingkan dengan perusahaan yang belum melaksanakan suatu budaya organisasi yang kuat (Megawati \& Nashri, 2015).

Perusahaan yang memiliki budaya kuat dapat membuat semua anggota yang terlibat dalam pelaksanaan menjadi fokus pada satu arah. Oleh sebab itu, perusahaan dengan visi dan misi serta memiliki budaya perusahaan yang kuat, mempunyai tingkat efektifitas dan efisiensi pelaksanaan realisasi strategi perusahaan yang lebih baik (Rakhman, 2018).

Competing values yang disampaikan oleh Quinn dan Cameron merupakan model yang cukup lengkap dalam menjelaskan keterkaitan budaya dengan berbagai aspek organsisasi. Model ini melakukan pengelompokan berdasarkan dua dimensi: (1) kriteria efektivitas dengan menekankan kepada organisasi untuk memiliki keleluasaan fleksibilitas, dan dinamika atau lebih menekankan stabilitas, kontrol dan keteraturan, (2) suatu kriteria efektivitas yang menekankan hubungan dengan luar organisasi, sistem yang terintegrasi, dan kesatuan atau lebih menekankan orientasi eksternal, diferensiasi, dan persaingan (rivalitas). Berdasarkan dua dimensi ini, empat kelompok nilai yang menggambarkan empat tipe organisasi, yaitu kultur klan, adhokrasi, market, dan hierarki (Kusumaningtyas \& Darmastuti, 2016).

Budaya yang dilaksanakan oleh sebuah perusahaan dapat diukur dengan konsistensi penilaian Cameron and Quinn (2006) mengembangkan survei yang disebut dengan Organizational Culture Assessment Instrument (OCAI). OCAI dapat digunakan sebagai alat untuk menilai arah organisasi yang dikelompokkan berdasarkan budaya yaitu hal yangsudah dilakukan oleh perusahaan dalam melaksanakan visi dan misi. Selain itu, dapat memberikan identifikasi bagi organisasi bagi setiap elemen di dalam suatu budaya (Umartias, 2014). 


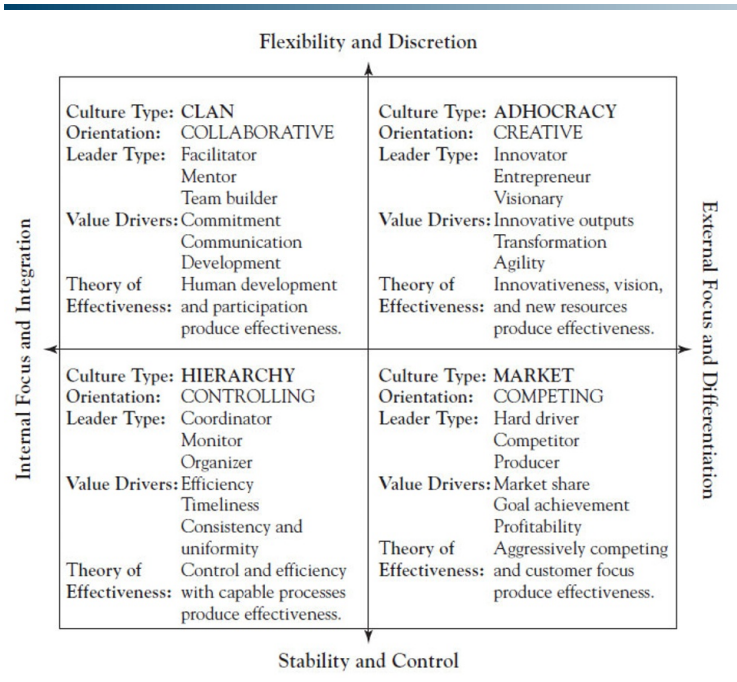

Gambar 1. The Competing Values of Leadership, Effectivenessand Organizational Theory (K. Cameron, 2007)

Analisis pemetaan budaya dengan metode yang menghasilkan suatu profil budaya pada pejabat struktural di RS Islam Surabaya dapat dilakukan pada kondisi tertentu. Penggambaran yang dilakukan Chatab (2007) sedikit berbeda dengan Cameron \& Quinn (2006), tetapi secara prinsip tidak mengubah dimensidimensi kuadran dari the competing value framework seperti tampilan pada Gambar 2. Tipologi budaya organisasi dapat dikategorikan dalam empat jenis, yaitu:

a) The clan culture

Clan culture merupakan suatu budaya yang memberikan suasana dan rasa senang saat bekerja, tempat setiap anggota yang saling bekerja sama dalam berbagi keterbukaan informasi secara pribadi, seperti halnya satu kesatuan keluarga besar. Pimpinan organisasi berperan sebagai guru dan sosok orang tua (Lizbetinova et al., 2016).

Organisasi ini memiliki perekat, yang dipegang teguh pada loyalitas dan tradisi sebagai satu kesatuan keluarga. Komitmen para anggota terhadap organisasi sangat tinggi (Lizbetinova et al., 2016). Organisasi memberikan tingkat kepentingan pada nilai kohesi dan moral untuk mengembangkan sumber daya manusia (Kusumaningtyas \& Darmastuti, 2016).

\section{b) The Adhocracy Culture}

Budaya ini merupakan lingkungan kerja yang memiliki perkembangan kreatif dan dinamis bagi setiap karyawan dalam mengambil risiko dari setiap tindakan yang dilaksanakan. Pada budaya ini, pemimpin berperan sebagai inovator dan pengambil risiko dari setiap keputusan (Putra \& Elyadi, 2020).

Setiap percobaan dan inovasi merupakan ikatan organisasi menuju budaya yang selalu berkembang dalam jangka panjang. Budaya ini didominasi oleh perilaku yang selalu tumbuh menemukan inovasi dan sumber daya baru (Putra \& Elyadi, 2020). Oleh karena itu, ketersediaan produk atau jasa baru dianggap sebagai hasil kesuksesan organisasi.

Organisasi memberikan kebebasan dalam kreativitas ide dan berkarya. Tipe pimpinan yang ada pada budaya ini adalah selalu menumbuhkan ide baru dan berjiwa kewirausahaan yang memiliki visi. Nilai penggerak merupakat hasil output yang berinovasi, bertransformasi, dan keleluasaan (Wijaya, 2016).

c) The Hierarchy Culture

Budaya kerja yang sangat kaku, terstruktur dan formal. Segala tindakan merupakan kegiatan yang terstruktur sesuai dengan aturan yang berlaku berdasarkan prosedur yang sudah ada. Nilai yang dianggap penting yaitu kebijakan formal dan kelancaran dalam menjalankan roda organisasi.

Pada budaya ini memberikan tindakan untuk visi jangka panjang yaitu stabilitas organisasi, kinerja, efisiensi, dan kelancaran operasional. Kesuksesan organisasi dapat dilihat dari tingkat penyerahan yang bisa diandalkan dalam pengelolaan, kelancaran dalam penjadwalan, dan efisiensi biaya. Selain itu, pengelolaan karyawan perlu dilakukan dengan berfokus pada setiap pekerjaan yang terjamin dan prediktabilitas hasil (Sani et al., 1999). 
Analisis Budaya Organizational Culture Assesment Instrument...

d) The Market Culture

Budaya ini memprioritaskan organisasi dalam menyelesaikan pekerjaan dengan cepat. Pada hal tersebut, seseorang memiliki jiwa persaingan dan memberikan fokus pada tujuan organisasi. Selain itu, terdapat pimpinan yang selalu dinamis dan memberikan motivasi, sekaligus memiliki jiwa bersaing. Anggota organisasi memiliki karakter tangguh, tidak mudah menyerah, dan memiliki pengharapan tinggi dalam menyelesaikan tujuan organisasi (Eko \& Hernawa, 2019).

Keberhasilan merupakan hal yang paling penting pada budaya ini. Pada jangka panjang memiliki tujuan yaitu organisasi selalu memiliki fokus bersaing dengan kompetitor dalam mencapai tujuan. Oleh karena itu, sistem diatur agar produk organisasi memiliki harga yang kompetitif dan unggul dibanding produk pesaing (Wijaya, 2016).

OCAI merupakan alat yang dapat digunakan untuk memberikan diagnosa budaya pada pelaksanaan suatu budaya dalam sebuah organisasi (Cameron, 2007). Hasil diagnosa berupa peragaan profil budaya organisasi.

Berdasarkan profil budaya organisasi yang diperoleh, dapat dilakukan berbagai interpretasi, seperti menganalisis dan menentukan jenis budaya dominan, kekuatan budaya, serta keserasian budaya. Instrumen OCAI diperkenalkan oleh Cameron \& Quinn (2006). Proses diawali dengan menanyakan kepada responden terkait keadaan sekarang dan keadaan yang diharapkan oleh karyawan dengan memberikan total penilaian dari setiap pertanyaan dengan nilai 100 (Imanuel, 2019).

\section{METODE PENELITIAN}

Penelitian ini merupakan penelitian deskriptif yang dilakukan dengan metode wawancara terstruktur dengan menggunakan angket. Penelitian ini dilakukan pada responden dari seluruh pejabat struktural dengan menggunakan Alat uji Organizational Culture Assessment Instrument (OCAI) (Nadirasetya et al., 2016). Sumber informasi adalah seluruh pejabat struktural di jajaran Rumah Sakit Islam yaitu berjumlah 63 pejabat. Setelah dilakukan pengisian angket, hasilnya diolah dengan menghitung rerata isian antara kondisi yang diinginkan dan kondisi saat ini.

\section{HASIL DAN PEMBAHASAN}

OCAI merupakan penilaian budaya yang akan mengklasifikasikan budaya suatu organisasi yang dikelompokkan menjadi enam jenis. Keenam jenis ini digunakan untuk menilai dari hasil kuisioner dengan karakteristik yang bisa diukur menggunakan perhitungan tertentu. Kuisiner tersebut yaitu: (1) Dominant characteristics (karakteristik dominan), (2) Organizational leadership (kepemimpinan organisasi), Management of employees (Manajemen karyawan), (4) Organization Glue (kerekatan organisasi), (5) Strategic emphases (penekanan pada strategi), (6) Criteria of success (kriteria keberhasilan) (Wijaya, 2016).

Tabel 1. Hasil Penilaian Kondisi Sekarang Budaya Organizational Culture Assesment Instrument (OCAI) Pejabat Struktural RS Islam Surabaya

\begin{tabular}{llcccc}
\hline No & Sekarang & Clan & Adochracy & Market & Hierarchy \\
\hline 1. & Dominan Karakteristik & 25,50 & 22,33 & 22,83 & 29,67 \\
2. & Kepemimpinan & 22,67 & 20,17 & 25,33 & 32,25 \\
3. & Manajemen SDM & 26,67 & 21,08 & 23,67 & 28,58 \\
4. & Kebersamaan & 31,25 & 21,33 & 21,50 & 26,50 \\
5. & Perioritas Strategy & 27,75 & 21,92 & 25,00 & 26,00 \\
6. & Kriteria Keberhasilan & 29,83 & 20,67 & 24,33 & 25,83 \\
\hline & 27,28 & 21,25 & 23,86 & 28,14 \\
\hline
\end{tabular}


Tabel 1 menunjukan hasil penilaian kondisi sekarang Budaya Organizational Culture Assesment Instrument (OCAI) Pejabat Struktural RS Islam Surabaya. Budaya yang sekarang didominasi oleh budaya Hierarchy dan budaya Clan.

Rumah sakit merupakan lembaga yang memberikan pelayanan kesehatan bagi pasien. Pentingnya clan culture dalam kolaborasi tim, yaitu budaya kerja ini memiliki rencana mentorship yang lebih matang dan solid dalam penanganan pasien. Ciri budaya kerja klan yaitu: (1) mentoring, (2) partisipasi, (3) kolaborasi tim, (4) kerja sama tim, (5) komitmen dan loyal, serta (6) musyawarah mufakat.

Pada penilaian sebuah organisasi meskipun tidak tertulis, pelanggan tetap dapat menilai dan merasakan kepribadian sebuah organisasi melalui budaya organisasi itu sendiri (Eko \& Hernawa, 2019). Apabila seseorang memutuskan untuk bergabung dalam sebuah organisasi, perilaku individu yang dipengaruhi budaya tempat tinggalnya masih melekat kuat (Putra \& Elyadi, 2020).

Budaya organisasi memiliki keterkaitan terhadap nilai, kepercayaan, dan norma. Pada pelaksanaanya, hal tersebut akan berbeda dari setiap individu. Namun, budaya organisasi diibaratkan sebagai suatu sistem bagi organisasi, bukan hanya salah satu individu saja.

Tabel 2. Hasil Penilaian Kondisi yang Diharapkan Budaya Organizational Culture Assesment Instrument (OCAI) Pejabat Struktural RS Islam Surabaya

\begin{tabular}{|c|c|c|c|c|c|}
\hline No & Sekarang & Clan & Adochracy & Market & Hierarchy \\
\hline & Dominan Karakteristik & 20,33 & 21,33 & 29,83 & 29,50 \\
\hline & Kepemimpinan & 23,08 & 23,25 & 24,33 & 29,08 \\
\hline & Manajemen SDM & 26,33 & 22,00 & 24,25 & 26,83 \\
\hline & Kebersamaan & 24,75 & 25,00 & 23,75 & 26,33 \\
\hline & Perioritas Strategy & 27,50 & 24,25 & 25,50 & 22,33 \\
\hline \multirow{2}{*}{\multicolumn{2}{|c|}{ 6. Kriteria Keberhasilan }} & 30,00 & 21,00 & 22,42 & 27,17 \\
\hline & & 25,33 & 22,81 & 24,90 & 26,88 \\
\hline
\end{tabular}

Tabel 2 memperlihatkan hasil penilaian kondisi yang diinginkan Budaya Organizational Culture Assesment Instrument (OCAI). Dari hasil tersebut diketahui bahwa kondisi yang diharapkan, didominasi oleh budaya Clan dan Hierarchy. Perbedaan nilai dan kepercayaan individu dengan organisasi dalam mencapai kesuksesan merupakan hal yang wajar. Untuk mengatasi adanya keanekaragaman nilai dan kepercayaan di antara anggota organisasi, maka sebelum seseorang bergabung harus diberikan pelatihan untuk menyamakan nilai dan kepercayaan atau mengenalkan budaya organisasi bagi anggota baru tersebut (Faizaty et al., 2020).

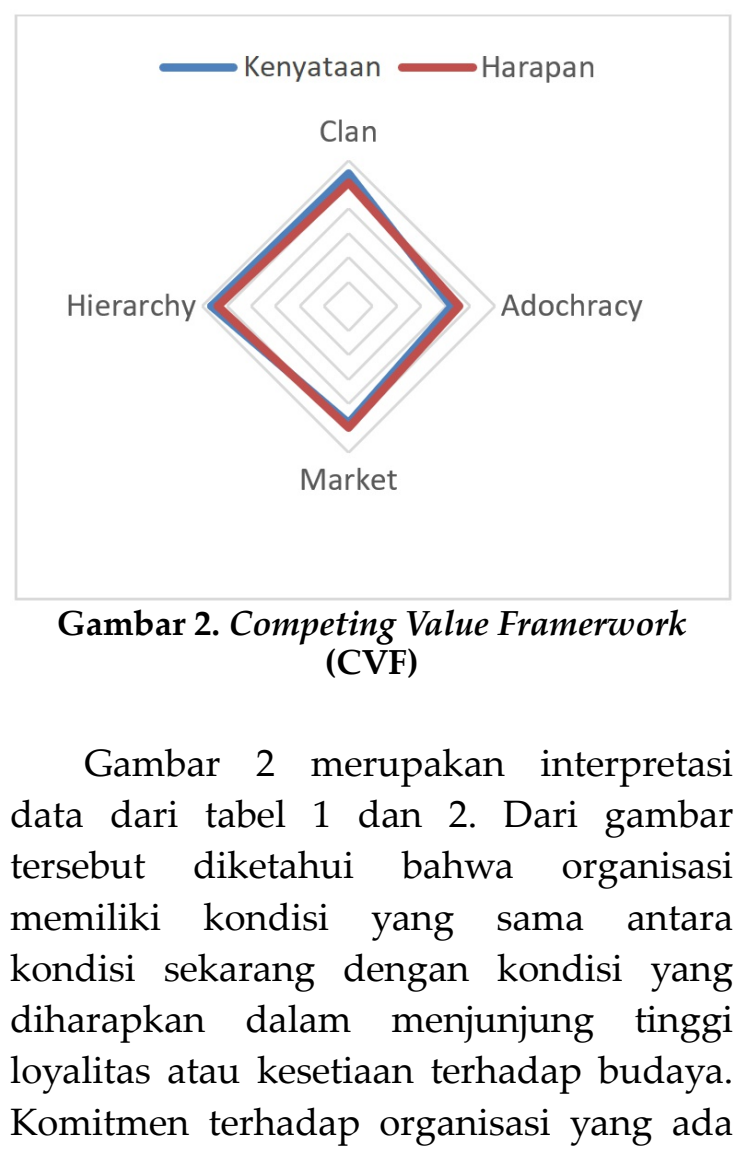


didalam setiap diri anggota sangat tinggi sehingga dari penilaian organisasi, didapatkan hasil penilaian yang sama, yaitu clan dan hierarchy.

Budaya clan merupakan suatu budaya yang memberikan suasana dan rasa senang untuk bekerja, tempat setiap anggota yang saling berbagi informasi pribadi, seperti sebuah kesatuan keluarga besar. Beberapa kelebihan Clan Culture adalah (1) Komunikasi internal yang solid, (2) Produktivitas kerja tinggi, dan (3) Terbuka dengan hal baru. Hal positif lain dari budaya ini adalah perusahaan cenderung terbuka dengan semua masukan dan saran dari setiap karyawan (Valas \& Raghunathan, 2018).

Menerapkan budaya clan dapat membuat karyawan lebih terbuka sehingga karyawan pun tak sungkan untuk berbicara dan berpendapat. Hal ini juga bisa mendorong perusahaan untuk lebih kreatif dan inovatif karena ide yang beragam dari karyawan. Pemimpin organisasi merupakanmentor dan tokoh yang berfungsi orang tua dalam budaya ini (Berkemeyer et al., 2015).

Budaya hierarchy memberikan suasana tempat kerja yang sangat formal dan terstruktur. Segala sesuatu yang dilakukan harus berdasarkan prosedur yang telah ditentukan. Para pemimpin selalu bangga menjadi koordinator yang baik dan memiliki pola pikir yang efisien (Dimitrios \& Koustelios, 2013).

Nilai yang dianggap penting pada budaya hierarchya dalah kebijakan formal dan kelancaran dalam menjalanakan roda organisasi. Visi jangka panjang organisasi dengan budaya hierarchya dalah stabilitas organisasi, kinerja, efisiensi, dan kelancaran operasional dalam melakukan suatu tindakan (Steinhoff \& Owens, 2015).

Kesuksesan organisasi merupakan tingkat penyerahan yang bisa diandalkan dalam pengelolaan, kelancaran dalam penjadwalan, dan efisiensi biaya. Pengelolaan karyawan berfokus pada setiap pekerjaan yang terjamin dan prediktabilitas dalam hasil (Hamid \& Mukzam, 2016).

Penelitian memberikan informasi tidak ada bedanya antara budaya clan dan budaya hierarchy. budaya hierarki adalah sebuah budaya kerja perusahaan yang berfokus pada perkembangan dan kestabilan peraturan, struktur, dan proses bisnis. Cara kerja adalah dengan menjunjung tinggi struktur manajemen yang ada di perusahaan.

Budaya clan dan hierarchy ini sangat erat dengan kontrol dan kekuasaan. Orang yang memiliki jabatan lebih tinggi, dan memiliki wewenang lebih untuk berkontribusi pada perusahaan, termasuk dalam hal. Budaya hierarki ini merupakan kebalikan dari. Kalau adhocracy culture dapat lebih fleksibel menerima masukan dari seluruh lapisan karyawan, tidak dengan hierarchical culture.

Sebuah keputusan dalam perusahaan yang menganut budaya hierarki biasanya akan datang dari pimpinan tertinggi. Banyak perusahaan besar yang masih menganut sistem ini adalah budaya kerja yang mengutamakan kepentingan kelompok dan rasa kekeluargaan di dalam perusahaan. Moto dari budaya kerja ini adalah "semua satu, satu untuk semua". Fokus dari clan culture kerja sama tim dan internal.

Beragam prinsip tersebut yang membuat perusahaan dengan clan culture juga unggul dalam hal kolaborasi tim. Biasanya juga, perusahaan dengan budaya kerja ini memiliki rencana mentorship yang lebih matang dan solid.

\section{KESIMPULAN}

Budaya Organizational Culture Assesment Instrument (OCAI) Pejabat Struktural RS Islam Surabaya, telah sesuai dengan apa yang dirasakan sekarang dengan apa yang menjadikan harapan dari seluruh pejabat struktural. Budaya Pejabat Struktural RS Islam Surabaya sekarang didominasi dengan budaya 
Hierarchy dan budaya Clan.

Budaya Hierarchy menunjukkan bahwa organisasi sudah memiliki tatanan dan mengharuskan seluruh pejabat di lingkungan RS Surabaya melakukan kebijakan tersebut. Setiap pemimpin yang terlibat di dalamnya merupakan koordinator dan organisator handal yang selalu memikirkan efisiensi dalam setiap tindakan. Budaya Clan menandakan bahwa RS Islam Surabaya merupakan tempat bekerja yang hangat, memiliki susana kekeluargaan, dan setiap individu yang ada saling mengisi satu sama lain mengenai diri mereka.

\section{DAFTAR PUSTAKA}

Berkemeyer, N., Bos, W., Müthing, K., \& Junker, R. (2015). Organizational cultures in education: Theory-based use of an instrument for identifying school culture. Journal for Educational Research Online Journal Für Bildungsforschung Online, 7(3), 86-102.

Cameron, K. (2007). An Introduction to the Competing Values Framework THE COMPETING

VALUES

FRAMEWORK. In An Introduction to the Competing Values Framework (pp. 1232). https://www.thercfgroup.com/ files/resources/

an_introduction_to_the_competing_v alues_framework.pdf

Cameron, K. S., \& Quinn, R. E. (2006). Diagnosing and Changing Organizational Culture. In The JosseyBass Business \& Management Series (Revised Ed). Jossey-Bass.

Chatab, N. (2007). Profil Budaya Organisasi: Mendiagnosis Budaya dan Merangsang Perubahannya(1st ed.). Alfabeta Bandung.

Dimitrios Belias, \& Koustelios, A. (2013). Organizational Culture of Greek Banking Institutions: a Case Study. International Journal of Human Resource Management and Research, 3(2), 95-104.

Eko, R. L., \& Hernawa, T. M. R. (2019). Pengukuran Budaya Organisasi
Organizational Culture Assessment

Instrument ." 146-152. https:/ejournal.usd.ac.id/index.php/JP/article/ view/835

Faizaty, N. E., Oktavia, R. M., \& Ilmawan, M. D. (2020). Implementasi Organizational Culture Assessment Instrument (Ocai) Untuk Pemetaan Budaya Organisasi Pt. Semen Indonesia (Persero) Tbk Sebagai Rujukan Winning Culture. Manajerial, 7(01), 37. https://doi.org/10.30587/ manajerial.v7i01.1047

Hamid, D., \& Mukzam, M. D. (2016). Peranan Pemimpin Dalam Mengembangkan Budaya Organisasi( Studi Kasus Pada Pt . Asuransi Jiwasraya ( Persero ) Malang Regional Office ). Administrasi Bisnis, 40(1), $\quad 152 . \quad$ http:// administrasibisnis.studentjournal.ub.a c.id/index.php/jab/article/view/1594

Imanuel. (2019). Analisis Budaya Organisasi Dengan Menggunakan Metode Organizational Culture Assesment Instrument (OCAI) Pada Perusahaan Air Minum (PDAM) Kabupaten Sikka. Jurnal Unippa, 6(1), 122. https://osf.io/zavtk/

Ira Setyaningsih. (2013). Peningkatan Akreditasi Rumah Sakit dalam Mengaplikasikan rumah sakit terhadap pasien menggunakan pendekatan lean servperf (lean service dan service performance. Spektrum Industri, 11(2g), 117-242.

Kusumaningtyas, Y., \& Darmastuti, I. (2016). Analisis Pemetaan Budaya Organisasi Mennggunakan Organizational Culture Assessment Instrument (Ocai) Pada Fakultas Ekonomika Dan Bisnis Universitas Diponegoro. Jurnal Studi Manajemen Organisasi, 13(1), 57. https://doi.org/ 10.14710/jsmo.v13i1.13413

Ližbetinová, L., Lorincová, S., \& Caha, Z. (2016). Primjena instrumenta procjene organizacione kulture (OCAI) na logističke tvrtke. Nase More, 63(3), 170- 
176. https://doi.org/10.17818/NM/2016/ SI17

Megawati, \& Nashri, M. F. (2015). Evaluasi Budaya Organisasi Dalam Penerapan Teknologi Informasi Menggunakan Organizational Culture Assessment Instrument (OCAI) Pada PT Perkebunan Nusantara V Pekanbaru. Jurnal Rekayasa Dan Manajemen Sistem Informasi, 1 Nomor 1(1), 17-30. http:// ejournal.uin-suska.ac.id/index.php/ RMSI/article/view/1301

Nadirasetya, N., Tama, I. P., \& ... (2016). Analisis Budaya Organisasi Menggunakan Metode Organizational Culture Assessment Instrument (OCAI) dan Pendekatan Fuzzy Linguistik. Jurnal Rekayasa ..., 8(2), 215222. http:// jrmsi.studentjournal.ub.ac.id/ index.php/jrmsi/article/view/523

Putra, A. H., \& Elyadi, R. (2020). Analisis Budaya Organisasi Pada Coffeeshop Atlas $n$ Co Menggunakan Organizational Culture Assesment Instrument (OCAI). Praxis, 3(1), 54. https://doi.org/10.24167/ praxis.v3i1.2822

Rakhman, A. (2018). Analisis Budaya Organisasi Menggunakan Metode Organizational Culture Assessment Instrument (OCAI). Jurnal Ilmu Manajemen Mulawarman, 3(4), 63-69. http://journal.feb.unmul.ac.id/ index.php/JIMM/article/view/1823

Sani, M. B., Yuliadi, I., \& Maryati, T. (1999). Pemetaan Budaya Organisasi Menggunakan Organization Culture Assessment Instrument Pada Rs Pku
Muhammadiyah Sruweng. Asosiasi Program Pascasarjana Perguruan Tinggi Muhammadiyah (APPPTM), 3, 77-88. http://repository.umy.ac.id/bitstream/ handle/123456789/2094/Artikel

Pemetaan BO.pdf? sequence $=1$

Steinhoff, C. R., \& Owens, R. G. (2015). The Organisational Culture Assessment Inventory: A Metaphorical Analysis in Educational Settings. Journal of Educational Administration, 27(3). https://doi.org/10.1108/ EUM0000000002463

Umartias, M. (2014). Pemetaan Budaya Organisasi Menggunakan Organizational Culture Assessment Instrument (OCAI) Pada PT Kereta Api Indonesia Daerah Operasional 4 Semarang. 1-15. https:// ejournal3.undip.ac.id/index.php/djom/ article/view/12934

Valas, S., \& Raghunathan, R. (2018). Assessing Organization Culture - A Review on the OCAI Instrument. International Conference on Management and Information Systems, 182-188.

Vidyastuti, V. (2019). Penerapan Organizational Culture Assessment Instrument (OCAI) terhadap Perumusan Visi dan Misi Perusahaan. Eksistensi, $\quad$ 1(1). http:// international.unmuhpnk.ac.id/ index.php/Eksis/article/view/1332

Wijaya, N. (2016). Pengelompokkan Kultur Budaya Fakultas Menggunakan Metode Organizational Culture Assessment Instrument (Ocai). Jurnal Manajemen Dan Bisnis: Performa, 0(1), 41-54. https://doi.org/10.29313/ performa.v0i1.3516 